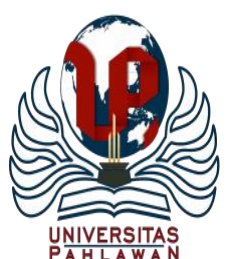

Jurnal Abdidas Volume 2 Nomor 4 Tahun 2021 Halaman 954-963

JURNAL ABDIDAS

http://abdidas.org/index.php/abdidas

\title{
Pelatihan Penggunaan eXeLearning sebagai Media Pembelajaran Online yang Interaktif
}

\author{
Mastiur Verawaty Silalahi ${ }^{1 凶}$, Natalina Purba $^{2}$, Sunggul Pasaribu ${ }^{3}$, Janwar Tambunan $^{4}$ \\ Pendidikan Biologi, Universitas HKBP Nommensen Pematangsiantar, Indonesia ${ }^{1}$ \\ Pendidikan Guru dan Sekolah Dasar, Universitas HKBP Nommensen Pematangsiantar, Indonesia ${ }^{2}$ \\ Pendidikan Agama Kristen, Universitas HKBP Nommensen Medan, Indonesia ${ }^{3,4}$ \\ E-mail: mastiur.verawaty@gmail.com ${ }^{1}$, natalinapurba@aol.com ${ }^{2}$, sunggul.pasaribu@gmail.com ${ }^{3}$, \\ janwar tambunan@yahoo.com ${ }^{4}$
}

\begin{abstract}
Abstrak
Guru-guru di sekolah SMA Swasta HKBP Hutabayuraja masih melakukan pembelajaran secara manual karena kurangnya kemampuan guru dalam bidang IT. Oleh karena itu, perlu dilakukan pelatihan penggunaan media interaktif untuk mendukung pembelajaran online pada saat pandemik Covid 19 ini. Media eXeLearning ini merupakan salah satu media interaktif yang dapat digunakan untuk mendukung pembelajaran secara online, karena pada eXeLearning guru dapat menyusun bahan ajar serta membuat soal latihan dalam bentuk web. Metode yang dilakukan adalah metode ceramah dan metode tutorial. Hasil dari pengabdian masyarakat ini adalah: 1) guru menjadi lebih percaya diri dan termotivasi menggunakan teknologi; 2) guru dapat merancang dan membuat bahan ajar dalam bentuk web sehingga membuat pembelajaran sederhana dan menarik sesuai tema dan kebutuhan peserta didik dengan menggunakan media eXeLearning; 3) guru dapat merancang soal latihan dalam bentuk web dan video menarik dan melibatkan anak dalam pembelajaran.
\end{abstract}

Kata kunci: media interaktif, eXeLearning, teknologi

\section{Abstract}

Teachers at private high school HKBP Hutabayuraja still do manual learning because of the lack of teacher skills in the IT field. Therefore, it is necessary to conduct training on the use of interactive media to support online learning during the COVID-19 pandemic. This eXeLearning media is one of the interactive media that can be used to support online learning, because in eXeLearning the teacher can compile teaching materials and create practice questions in web form. The method used is the lecture method and the tutorial method. The results of this community service are: 1) teachers become more confident and motivated to use technology; 2) teachers can design and create teaching materials in web form so as to make learning simple and interesting according to the themes and needs of students by using eXeLearning media; 3) teachers can design practice questions in the form of interesting web and videos and involve children in learning.

Keywords: interactive media, eXeLearning, technology

Copyright (c) 2021 Mastiur Verawaty Silalahi, Natalina Purba, Sunggul Pasaribu, Janwar Tambunan

$\triangle$ Corresponding author

Address : Lorong 8 Komplek Veteran Perumahan Bintang Bersinar

Email : mastiur.verawaty@gmail.com

DOI : https://doi.org/10.31004/abdidas.v2i4.404

ISSN 2721-9224 (Media Cetak)

ISSN 2721- 9216 (Media Online) 
955 Pelatihan Penggunaan Exe-Learning sebagai Media Pembelajaran Online yang Interaktif - Mastiur Verawaty Silalahi, Natalina Purba, Sunggul Pasaribu, Janwar Tambunan

DOI: https://doi.org/10.31004/abdidas.v2i4.404

\section{PENDAHULUAN}

Dampak pandemik Covid 19 terlihat sangat besar pada dunia pendidikan. Dunia pendidikan dituntun untuk melakukan perubahan yang sangat besar, di mana yang dulunya pembelajaran dengan tatap muka, harus dilakukan dengan pembelajaran dalam jaringan (online). Pembelajaran secara daring dilakukan di segala level pendidikan mulai dari SD, SMP, SMA dan Perguruan Tinggi (PT). Pembelajaran pada saat ini dituntut harus menggunakan media pembelajran interaktif agar menarik keinginan peserta didik untuk mengikuti pembelajaran secara daring. Setiap komponen yang terlibat serta juga harus melakukan aktivitas secara daring.

Guru merupakan salah satu komponen utama bidang pendidikan yang menjadi faktor penentu tinggi rendahnya kualitas hasil pendidikan. Terkait kompetensi profesional, dalam PP Nomor 74 Tahun 2008 menjabarkan bahwa diharapkan memiliki kemampuan dalam menguasai pengetahuan di bidang ilmu pengetahuan, teknologi, dan/atau seni dan budaya. Sehingga dalam hal ini, profesionalisme seorang guru bukan hanya sekedar mengajar (transfer of knowledge), melainkan setiap guru diharapkan mampu menciptakan kondisi belajar yang menantang kreativitas dan aktivitas siswa, memotivasi siswa, menggunakan multimedia, multimetode, dan multi sumber agar mencapai tujuan pembelajaran yang diharapkan (Rusman, 2011).

Sistem pembelajaran daring dilaksanakan melalui perangkat Personal Computer (PC) atau laptop yang terhubung dengan koneksi jaringan internet. Guru dapat melakukan pembelajaran bersama diwaktu yang sama menggunakan grup di media sosial seperti WhatsApp (WA), Telegram, aplikasi Zoom, Google Classroom ataupun media lainnya sebagai media pembelajaran. Dengan demikian, guru dapat memastikan siswa mengikuti pembelajaran dalam waktu yang bersamaan, meskipun di tempat yang berbeda (Azizah, 2020).

Hal ini menjadi tantangan yang besar bagi guru. Guru juga dalam mempersiapkan bahan materi ajar yang akan disampaikan kepada siswa harus menarik dan lebih mudah dimengerti, baik teori maupun praktikum dengan menterjemahkan menggunakan simulasi, rumusan, tabel, grafik dan gambar-gambar. Dapat juga menggunakan rekaman suara,tampilan video konferensi langsung dengan beberapa aplikasi media penunjang dengan siswa jika dibutuhkan adanya penjelasan materi khusus yang mendalam, misalnya perhitungan matematika, rumus kimia dan biologi: bahasa latin (Parinduri et al., 2021).

Media pembelajaran merupakan salah satu jenis perangkat pembelajaran yang berisi materi pelajaran dan penugasan terhadap siswa. Media pembelajaran dapat diartikan segala sesuatu yang dapat digunakan untuk menyampaikan informasi secara terencana sehingga menghasilkan suasana belajar yang kondusif dan siswa sebagai penerima informasi dapat melaksanakan proses pembelajaran yang efektif dan efisien (Munaidi, 2010). Media memiliki peran yang sangat penting dalam proses pembelajaran karena dapat membantu memberikan kejelasan atas ketidakjelasan informasi yang disampaikan (Wijayanti et al., 2018). Media pembelajaran dapat 
956 Pelatihan Penggunaan Exe-Learning sebagai Media Pembelajaran Online yang Interaktif - Mastiur Verawaty Silalahi, Natalina Purba, Sunggul Pasaribu, Janwar Tambunan

DOI: https://doi.org/10.31004/abdidas.v2i4.404

dijadikan sebagai sarana penyalur informasi dari guru kepada siswa. Dengan demikian, siswa akan lebih mudah mempelajari dan memahami materi.

Program E-learning merupakan salah satu media yang menggunakan teknologi komputer yang dapat digunakan sebagai media pembelajaran. Program E-learning banyak dikembangkan dengan berbagai karakteristik dasar yakni memberikan layanan student self service, online learning, online assessment, collaborative learning, training resources management (Sukari, 2014). Menurut Mafeny (Mafenya, 2013) Elearning efektif dan dapat meningkatkan pendidikan di mana E-learning tersebut dirancang dengan baik dan proses pembelajaran berpusat pada siswa. Salah satu media E-learning itu adalah eXeLearning. Bahan ajar yang disusun dengan eXe, tersusun secara hierarki yang benar mencakup topic, section dan unit. Susunan yang demikian akan memudahkan mahasiswa untuk lebih memahami materi perkuliahan. Dalam eXe juga dapat dibuat soal dengan tipe pilihan ganda, jawaban singkat, benar-salah dan kuis sehingga dapat dipergunakan untuk uji kompetensi mahasiswa (Warjana, 2008).

\section{METODE}

\section{Kerangka Pemecahan Masalah}

Selama pembelajaran secara daring guruguru masih mengalami kesulitan dikarenakan kurangnya pengetahuan guru tentang jenis-jenis media pembelajaran. Sebagian besar guru-guru hanya melakukan pembelajaran via WhatsApp group, Google Classroom dan Zoom Meeting. Sementara untuk materi perhitungan sulit di jelaskan dengan media tersebut. Oleh karena itu, sangat perlu adanya media yang mendukung untuk materi seperti perhitungan. Media pendukung tersebut merupakan media eXeLearning.

\section{Khalayak Sasaran Strategi}

Khalayak sasaran dari kegiatan ini adalah Guru SMA Swasta HKBP Hutabayuraja. Media eXeLearning ini akan mempermudah guru-guru untuk mengajarkan materi berupa perhitungan pada pembelajaran daring saat pandemik Covid 19.

\section{Keterkaitan}

Kegiatan ini dipandang tepat dan memiliki keterkaitan dengan khalayak sasaran yaitu Guruguru SMA Swasta HKBP Hutabayuraja. Guruguru tersebut merupakan orang yang berperan penting dalam proses pelatihan penggunaan media eXeLearning tersebut.

\section{Metode Kegiatan}

Metode kegiatan yang dilakukan adalah pelatihan penggunaan media eXeLearning sebagai media pembelajaran online yang interaktif khususnya pada masa pembelajaran daring ini.

\section{Rancangan Evaluasi}

Evaluasi keberhasilan dari kegiatan ini adalah Guru-guru SMA Swasta HKBP Hutabayuraja sudah dapat menggunakan media eXeLearning sebagai media pembelajaran interkatif saat pembelajaran daring. Indikator keberhasilan kegiatan ini dilihat dari respon positif dari para peserta melalui evaluasi yang diberikan. Evaluasi kegiatan juga dilakukan berupa kuesioner 
957 Pelatihan Penggunaan Exe-Learning sebagai Media Pembelajaran Online yang Interaktif - Mastiur Verawaty Silalahi, Natalina Purba, Sunggul Pasaribu, Janwar Tambunan

DOI: https://doi.org/10.31004/abdidas.v2i4.404

yang diisi peserta, terkait dengan kegiatan yang telah diikuti. Kemampuan pemahaman peserta diperoleh berdasarkan hasil evaluasi terhadap Guru SMA Swasta HKBP Hutabayuraja. Peserta akan diberikan sertifikat sebagai bukti keikutsertaan dalam kegiatan ini.

\section{Tempat, Waktu dan Susunan Acara}

Berikut waktu dan lokasi pelaksanaan pengabdian Masyarakat di SMA Swasta HKBP Hutabayuraja:

Hari/ Tanggal : Senin-Selasa, 14-15 Juni 2021 Waktu : $09.00-14.00 \mathrm{WIB}$

Alamat : Jln. S.M Raja No. 158 Hutabayuraja

Susunan Acara pada pengabdian masysrakat di SMA Swasta HKBP Hutabayuraja:

Hari Pertama:

a. Pembukaan

b. Sambutan dari Praeses dan Kepala Sekolah SMA Swasta HKBP Hutabayuraja

c. Penyampaian materi dan tata cara penggunaannya tentang aplikasi eXeLearning.

d. Diskusi dan tanya jawab

e. Penutup

Hari Kedua :

a. Pembukaan

b. Pembagian kelompok guru menjadi beberapa kelompok

c. Melakukan tutorial langsung bersama guruguru oleh pelaksana pengabdian masyarakat.

d. Melakukan evaluasi melalui pemberian angket yang harus diisi oleh guru.

e. Penutup

\section{HASIL DAN PEMBAHASAN}

Pada tahap persiapan, tim PKM melakukan observasi dengan Kepala Sekolah SMA Swasta HKBP Hutabayuraja untuk mengetahui kondisi awal guru di sekolah tersebut. Berdasarkan hasil observasi diperoleh informasi bahwa guru-guru di sekolah tersebut belum menggunakan IT sebagai media pembelajaran khususnya pada masa pandemik Covid-19. Selanjutnya, hasil observasi yang dilakukan langsung ke guru-guru bahwa mereka masih menggunakan WhatsApp Grup dalam proses pembelajaran.

Pada tahap pelaksanaan, kegiatan pengabdian masyasrakat yang dilakukan di SMA Swasta HKBP Hutabayuraja diikuti oleh 17 peserta. Peserta kegiatan terdiri dari kepala sekolah, guru dan praeses, sementara tim pengabdian kepada masyarakat terdiri atas dosen Universitas HKBP Pematangsiantar. Pelatihan dibuka oleh praeses dan kepala sekolah.

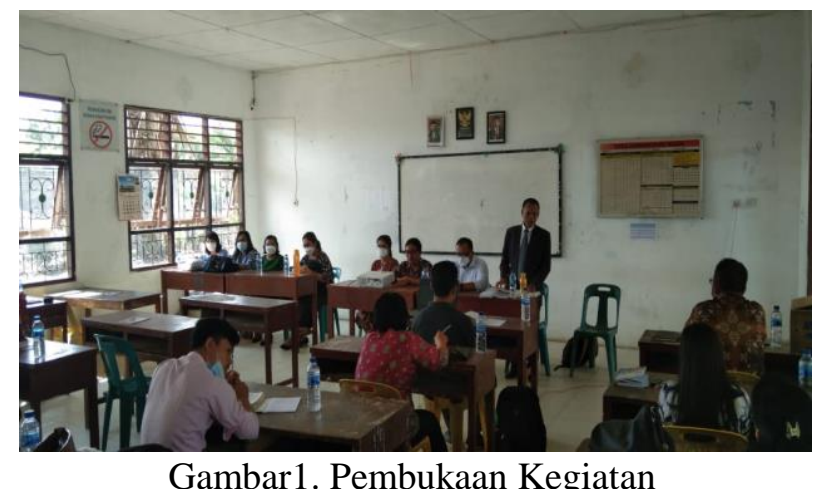

Gambar1. Pembukaan Kegiatan

Setelah itu kegiatan dilanjutkan dengan penyampaian materi tentang pengenalan media, manfaat serta langkah-langkah penggunaan media. Pada hari kedua, dilakukan pendampingan penggunaan media eXeLearning. Peserta dibagi atas 4 kelompok yang masing-masing kelompok 
958 Pelatihan Penggunaan Exe-Learning sebagai Media Pembelajaran Online yang Interaktif - Mastiur Verawaty Silalahi, Natalina Purba, Sunggul Pasaribu, Janwar Tambunan

DOI: https://doi.org/10.31004/abdidas.v2i4.404

dipandu oleh 2 dosen. Setiap dosen berperan dalam membantu dan mengarahkan peserta dalam penggunaan media eXeLearning.

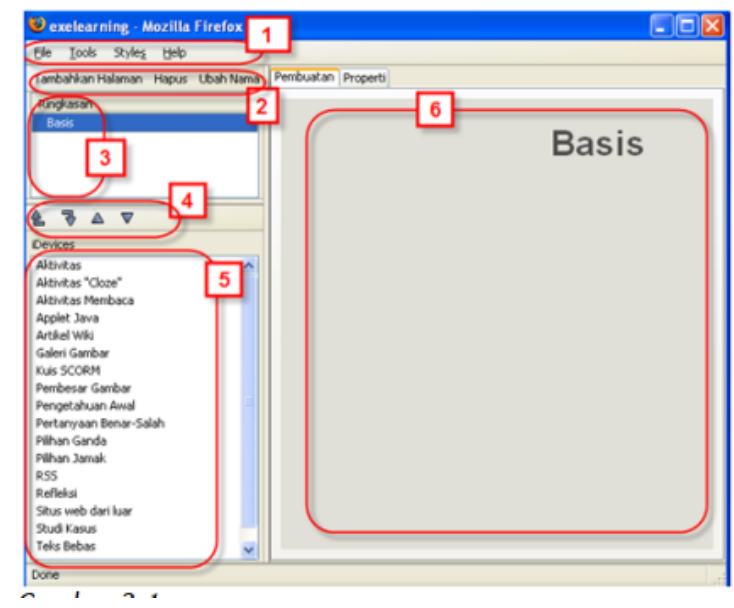

Gambar 2. Aplikasi EXeLearning

Aplikasi eXeLearning lebih efektif dan efisien dalam proses pembelajaran, karena materi yang diberikan guru dengan media eXeLearning tersebut bisa langsung disimpan dan dapat diulangulang oleh siswa dalam bentuk presentasi dan tutorial. Selain itu materi yang disimpan oleh siswa dapat diakses di mana saja dan kapan saja tanpa menggunakan paket data seluler. Penjelasan tentang pengenalan media eXeLearning sebagai berikut:

- Pertama-tama, instal aplikasi eXeLearning bisa di download secara gratis di http://exelearning.org atau di http://exelearning.net/downloads/ $\quad \mathrm{di}$ komputer atau laptop Anda.

- Setelah download, pengaturan exe, pilih bahasa (bahasa Indonesia) - browser default- browser Mozilla Firefox - simpan

- Menu And Toolbar, menyediakan menumenu yang berlaku secara global
- Outline Pane and Title Nodes, menu untuk manage struktur materi pelatihan seperti bab, sub bab, seksi dan seterusnya.

- Menambah halaman, menghapus, dan merubah nama.

- Tampilan struktur halaman.

- Untuk memindahkan section ke posisi atas atau bawah.

- Idevices, modul yang tersedia yang bisa di tambahkan kedalam halaman terdiri dari berbagai macam fungsi. Misalnya untuk membuat halaman yang bertujuan supaya siswa membaca gunakan Idevice Aktivitas Membaca, untuk membuat halaman latihan berganda gunakan Idevice pilihan ganda.

- Lembar kerja. Double klik pada Idevice maka akan ditampilkan pada lembar kerja.

\section{Memulai Bekerja Dengan eXeLearning}

- Tampilan awal eXeLearning seperti di atas. Untuk memulai membuat, rubahlah nama standar basis menjadi judul sesuai yang diinginkan klik pada ubah nama, lihat gambar 3.

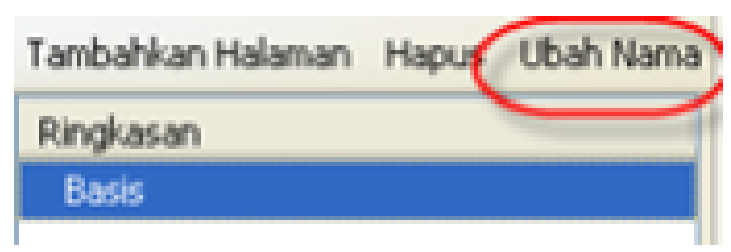

Gambar 3 Tampilan Cara Merubah Nama

- Ganti sesuai yang diinginkan, misalnya "Modul Penggunaan GPS Handled" kemudian klik ok, Gambar 4 
959 Pelatihan Penggunaan Exe-Learning sebagai Media Pembelajaran Online yang Interaktif - Mastiur Verawaty Silalahi, Natalina Purba, Sunggul Pasaribu, Janwar Tambunan

DOI: https://doi.org/10.31004/abdidas.v2i4.404

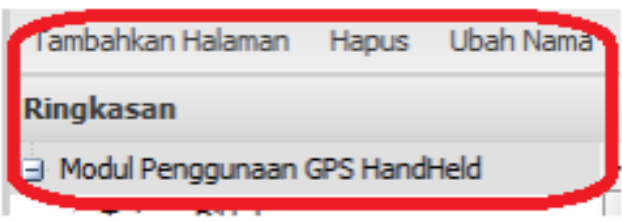

Gambar 4 Tampilan Nama Setelah Dirubah

- Setelah itu pilih Idevice (modul) yang diinginkan pada halaman ini, misalnya kita ingin memasukan halaman yang beri teks dan gambar bebas, klik pada modul teks bebas pada Idevice, Gambar 5

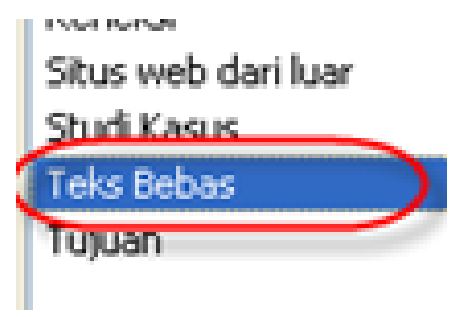

Gambar 5 Cara Memasukkan Halaman yang Ingin Diberi Teks dan Gambar.

- Lihat pada gambar 5 dibawah ini yaitu ruang kerja untuk membuat halaman modul.

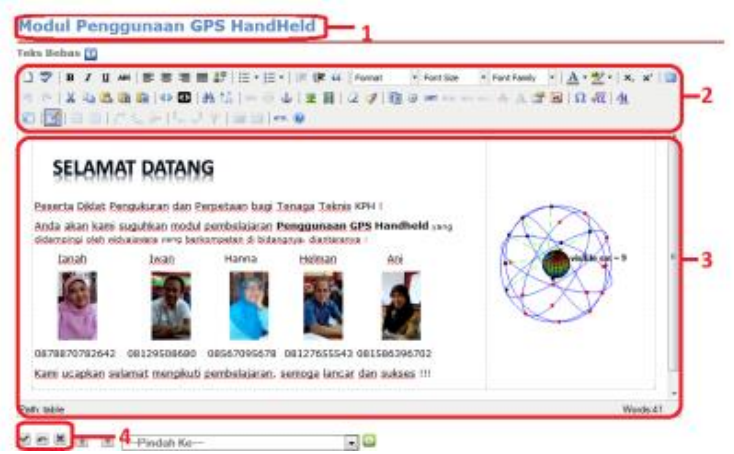

Gambar 5. Gambar Ruang Kerja

Keterangan Gambar 5:

1. Judul/nama halaman pada ringkasan.

2. Toolbar untuk memanipulasi text, memasukan gambar dan sebagainya.
Tombol hampir sama dengan micorsoft word

3. Isi dari halaman yang dibuat

4. Menu untuk selesai mengedit (centang), batal mengedit dan menghapus (silang).

Setelah selesai mengedit klik pada tombol centang (menu 4). Hasilnya seperti pada gambar 6 berikut ini :

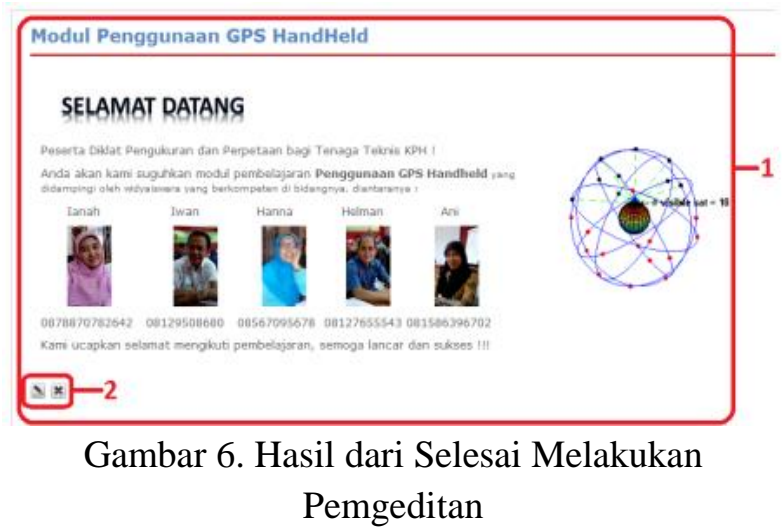

Keterangan Gambar 6:

1. Isi halaman yang telah dibuat.

2. Gambar pensil untuk mengedit halaman yang telah dibuat, dan gambar silang $[\mathrm{x}]$ untuk menghapus halaman.

Selanjutnya jika akan membuat halamanhalaman untuk modul-modul yang lain. Klik pada tambahkan halaman, kemudian posisikan dibawah halaman utama atau di sub halaman. Kemudian rubah nama sesuaikan dengan isi. Sehingga terbentuk hirarki halaman. 
960 Pelatihan Penggunaan Exe-Learning sebagai Media Pembelajaran Online yang Interaktif - Mastiur Verawaty Silalahi, Natalina Purba, Sunggul Pasaribu, Janwar Tambunan

DOI: https://doi.org/10.31004/abdidas.v2i4.404

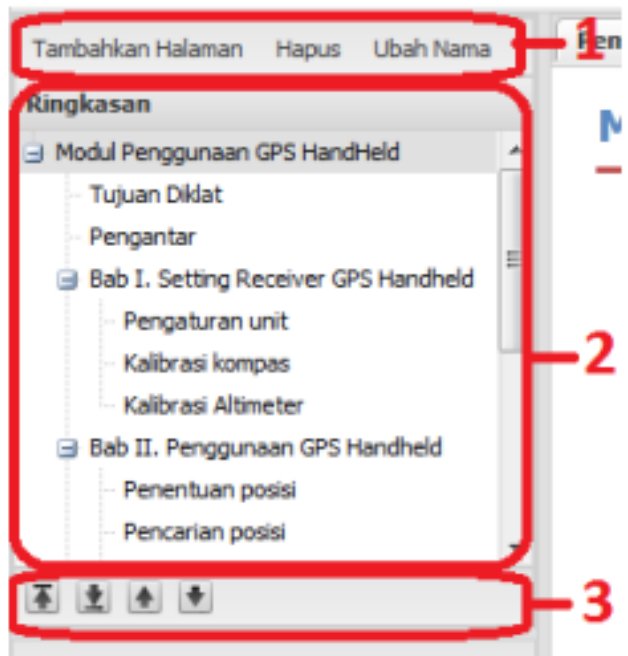

Gambar 7 Cara Menambah Halaman-halaman

Keterangan Gambar 7:

1. Untuk menambah halaman, menghapus halaman dan membuat/mengubah nama/judul halaman.

2. Hirarki halaman-halaman yang telah dibuat.

3. Tanda panah up-down untuk menentukan hirarki halaman.

\section{- Membuat Halaman Latihan}

Buat halaman baru kemudian beri nama "Ujian Mandiri", kemudian masukan Idevice (modul) dan pilih Interactive Activities, pilihlah misalnya pilihan ganda, lihat gambar 8 .

\begin{tabular}{l} 
iDevices - \\
$\boxplus$ Experimental \\
\hline$\exists$ Interactive Activities \\
\hline Aktivitas "Cloze" \\
DropDown Activity \\
Kuis SCORM \\
Pertanyaan Benar-Salah \\
Plihan Ganda \\
Plihan Jamak
\end{tabular}

Gambar 8.Cara Membuat Halaman Latihan
Setelah jenis latihan dipilih, selanjutnya isi pertanyaan, petunjuk, jawaban benar dan salah, umpan balik seperti yang terlihat pada gambar 9 berikut ini :

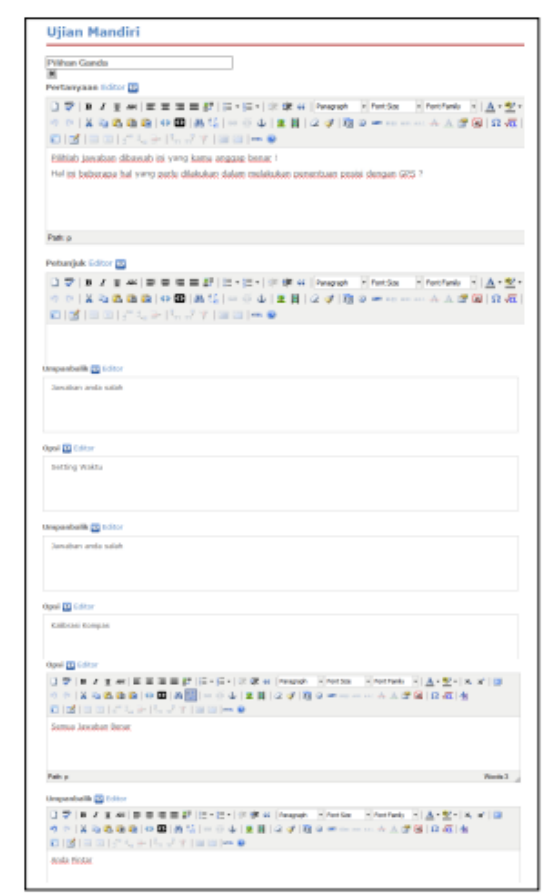

Gambar 9. Tampilan Halaman Latihan

Keterangan Gambar 9 :

1. Pada pertanyaan masukan pertanyaan.

2. Beri petunjuk cara menjawab dan jika tidak ingin ada petunjuk boleh dikosongkan saja.

3. Opsi adalah pilihan jawaban, masukan pilihan jawaban, pilihan jawaban dimasukan satu persatu.

4. Umpan balik, isikan umpan balik dari opsi jawaban, misalnya opsi salah beri umpan balik "Jawaban salah."

5. Option, beri centang pada option jika jawaban benar, klik tanda silang jika ingin menghapus opsi jawaban.

Klik pada tambahkan opsi untuk menambahkan opsi jawaban dan klik "Tambahkan 
pertanyaan yang lain” jika ingin menambahkan pertanyaan, setelah selesai membuat halaman latihan maka klik tanda centang. Lihat gambar berikut:

\section{Tambahkan opsi yang lain \\ Tambahkan pertanyaan yang lain}

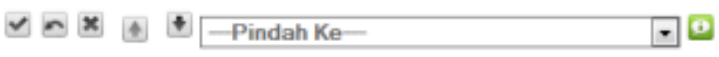

Gambar 10. Tampilan Opsi

Lihat hasil halaman latihan yang telah dibuat tadi seperti pada gambar 11 :

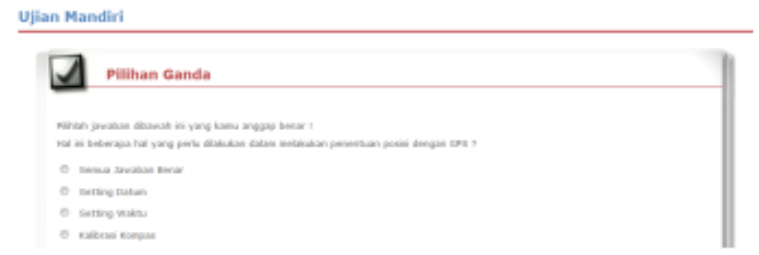

Gambar 11. Hasil Pembuatan Soal Ujian Mandiri

Untuk membuat jenis latihan lainnya silakan pilih jenis latihannya, caranya hampir sama dengan pilihan ganda.

Setelah langkah-langkah di atas, dalam penggunaan aplikasi media eXeLearning banyak guru yang antusias menggunakan eXeLearning dengan membuat materi pelajaran sesuai dengan bidang keahlian masing-masing. Pemanfaatan media eXeLearning dilakukan setiap guru mata pelajaran akan diaplikasikan secara langsung pada pembelajaran secara daring.

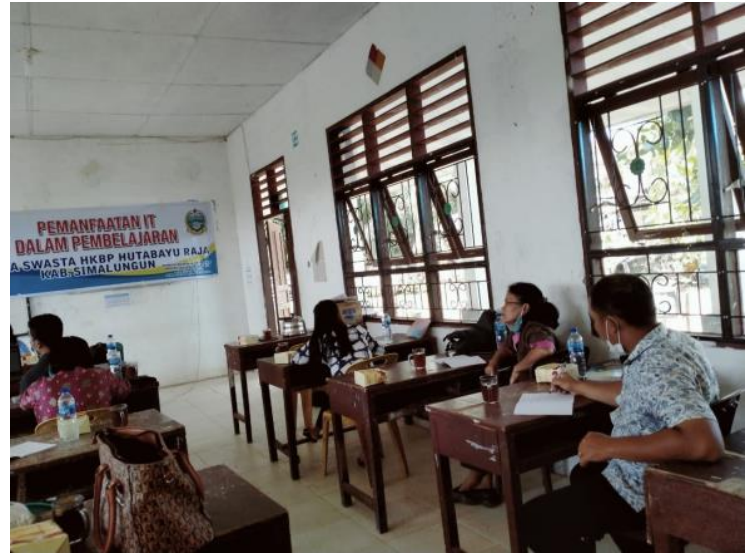

Gambar 12. Kegiatan Pelatihan Penggunaan Media EXeLearning

Pada Gambar 12 di atas, terdapat interaksi antara peserta dan nara sumber dimana terjadi tanya jawab mengenai media pembelajaran yang ditampilkan. Kendala yang ditemukan pada gambar di atas adalah guru-guru banyak yang kurang mengerti teknologi sehingga langkahlangkah terurut penggunaan media eXeLearning tidak dapat dilakukan secara bersamaan. Solusi mengatasi kendala di atas peserta pelatihan dibagi atas empat kelompok yang masing-masing kelompok akan dipandu oleh dua dosen. Sehingga, bila ada guru yang tertinggal dalam mengikuti langkah-langkah tersebut dapat dibantu oleh dosen yang memandu kelompok tersebut.

Pada tahap evaluasi dilakukan kegiatan berupa pemberian angket yang bertujuan untuk melihat sejauh mana keberhasilan proses pelaksanaan PKM. Hasil angket kegiatan PKM dipaparkan dalam bentuk grafik sebagai berikut : 


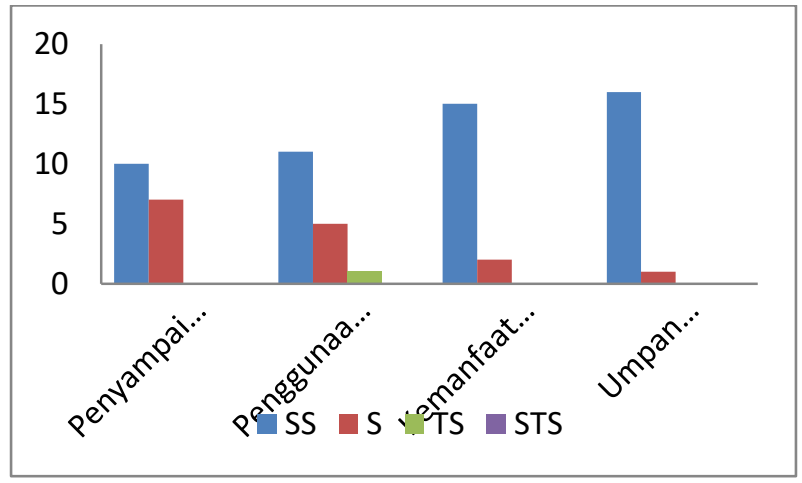

Gambar 12. Hasil Angket Umpan Balik

Keberhasilan Proses Pelaksanaan PKM

Berdasarkan grafik diatas, $58,82 \%$ peserta menyatakan sangat setuju pada indikator penyampaian materi dan $41,17 \%$ peserta yang menyatakan setuju. Pada indikator kedua yaitu penggunaan media eXeLearning menyatakan 64,79\% sangat setuju, 29,41\% menyatakan setuju, dan 5,88\% menyatakan tidak setuju. Untuk indikator ketiga yaitu kemanfaatan kegiatan, $88,23 \%$ menyatakan sangat setuju dan $11,76 \%$ menyatakan setuju. Untuk indikator terakhir yaitu indikator keempat yaitu umpan balik kegiatan, $94,11 \%$ menyatakan sangat setuju, dan 5,88\% menyatakan setuju. Hal ini memperlihatkan semangat dan antusiasme guru dalam mengikuti pelatihan tersebut.

Pelaksanaan pelatihan ini juga membantu guru dalam mengoptimalkan pembelajaran daring serta memberikan konstribusi terhadap pengetahuan guru dalam menggunakan media eXeLearning. Sejalan dengan penelitian (Teknologi et al., 2010) menyatakan dengan program ini, diharapkan guru-guru di sekolah, terutama guru kimia, dapat membuat suatu media pembelajaran yang interaktif sehingga menarik minat dan meningkatkan pemahaman kimia siswa serta menciptakan suasana belajar yang menyenangkan. Serta pada penelitian (Manulang et al., 2020) menyatakan dari hasil penelitian, diperoleh nilai validasi dengan skor $94,35 \%$ oleh validator media dan $88,12 \%$ oleh validator materi. Skor respon pengguna oleh guru dan peserta didik masing-masing adalah 93,3\% dan 92\% dengan kriteria sangat baik. Kegiatan pelatihan pembuatan media pembelajaran yang dilaksanakan oleh guruguru dapat mengubah kreativitas guru dalam membuat media pembelajaran yang interaktif.

\section{SIMPULAN}

Dari kegiatan pengabdian kepada masyarakat yang telah dilakukan dapat disimpulkan bahwa guru telah memperoleh pengetahuan dan keterampilan tentang penggunaan media eXeLearning. Melalui pelatihan ini guru lebih mengetahui tentang penggunaan media eXeLearning dan dapat mengoptimalkan penggunaanya dalam pembelajaran secara daring.

Respon dari peserta menunjukkan bahwa kegiatan seperti ini perlu untuk dilaksanakan guna membekali guru untuk melakukan pembelajaran daring lebih efektif.

\section{UCAPAN TERIMA KASIH}

Tim pengabdian kepada masyarakat mengucapkan terima kasih kepada LPPM Universitas HKBP Nommensen Pematangsiantar, Kepala Sekolah dan para Guru SMA Swasta HKBP Hutabayuraja yang telah memfasilitasi kegiatan pengabdian ini sehingga terlaksana dengan baik. 
963 Pelatihan Penggunaan Exe-Learning sebagai Media Pembelajaran Online yang Interaktif - Mastiur Verawaty Silalahi, Natalina Purba, Sunggul Pasaribu, Janwar Tambunan

DOI: https://doi.org/10.31004/abdidas.v2i4.404

\section{DAFTAR PUSTAKA}

Agustina, I., Astuti, D., Sumarni, R. A., \& Bhakti, Y. B. (2019). PENGEMBANGAN MULTIMEDIA INTERAKTIF BERBASIS. 2(2), 107-114.

Azizah, A. (2020). Pelatihan Pembelajaran Daring Dimasa Pandemi Covid-19 Untuk GuruGuru Sd Negeri 3 Melayu Muara Teweh. Bakti Banua: Jurnal Pengabdian Kepada Masyarakat, $\quad 1(2), \quad 78-83$. https://doi.org/10.35130/bbjm.v1i2.152

Mafenya, P. N. (2013). An investigation of firstyear students' pedagogical readiness to elearning and assessment in open and distance learning: An university of South Africa context. Mediterranean Journal of Social Sciences, 4(13), 353-360. https://doi.org/10.5901/mjss.2013.v4n13p353

Manulang, E., Linda, R., Noer, A. M., Studi, P., Kimia, P., Keguruan, F., Universitas, P., \& Km, K. B. (2020). Jurnal Pendidikan Kimia Universitas Riau PENGEMBANGAN EMODULE KIMIA BERBASIS EXELEARNING PADA. 5(2), 70-77.

Munaidi, Y. (2010). Media Pembelajaran. Gaung Persada Press.

Parinduri, I., Hutagalung, S. N., \& Sitohang, N. (2021). Pembuatan Video Confrensi Menggunakan Media Zoom Meeting Dan Pembuatan Sertfikat Pelatihan Menggunakan Google Form. 1(2), 43-48.

Rahmi, E., \& Cerya, E. (2019). Upaya Peningkatan Kompetensi Pedagogik Guru Smk Bisnis Manajemen Kabupaten Agam Melalui Pelatihan Pembuatan Video Pembelajaran. Amaliah: Jurnal Pengabdian Kepada Masyarakat, 3(2), 314-320. https://doi.org/10.32696/ajpkm.v3i2.284

Rusman. (2011). Model-Model Pembelajaran Mengembangkan Profesionalisme Guru. PT Raja Grafindo Persada.

Sukari. (2014). Mengembangkan E-Learning Sekolah. Penerbit Erlangga.

Teknologi, P., Dalam, I., \& Kimia, P. (2010). PEMANFAATAN PROGRAM APLIKASI eXe ( E LEARNING XHTML EDITOR ). 2009, 91-95.
Warjana, R. dan. (2008). Membuat Bahan Ajar Berbasis Web dengan eXe. Elexmedia Komputindo.

Wijayanti, R., Hasan, B., \& Loganathan, R. K. (2018). Media comic math berbasis whiteboard annimation dalam pelajaran matematika. Jurnal Riset Pendidikan Matematika, 5(1), 53. https://doi.org/10.21831/jrpm.v5i1.19207 